\section{Arip Suprianto}

Magister Ilmu Pemerintahan Universitas

Muhammadiyah Yogyakarta

Email: arip_guntung @yahoo.com

\section{Dyah Mutiarin}

Dosen Magister IImu Pemerintahan

Universitas Muhammadiyah Yogyakarta

Email: mutiarin@yahoo.com

https://doi.org/10.18196/jgpp.4172

\section{EVALUASI PELAKSANAAN JAMINAN KESEHATAN NASIONAL}

\author{
(Studi Tentang Hubungan Stakeholder, Model
}

Pembiayaan dan Outcome JKN di Kabupaten

Bantul Provinsi Daerah Istimewa Yogyakarta)

\begin{abstract}
Health care is one of the fundamental rights of the people who held the government as mandated in the 1945 Constitution Article $28 \mathrm{H}$ Paragraph (1) Everyone has the right to live physically and mentally prosperous, residence and got a good environment and healthy and receive medical care. Social Security Agency consists of BPJS BPJS Health and Employment which will cover the entire population of Indonesia no later than January 1, 2019. Services BPIS many people questioned. According to Assistant Representative ORI D.I.Y. Reports BPJS services complaints procedure is quite high in 2015. There are also complaints of them in the management of the bureaucracy, registration, until the queues are long and the related payment. Of the existing problems researchers aim to investigate the implementation of the National Health Insurance (JKN) focused on Stakeholder Relations, Financing Model and Outcome JKN in Bantul. This research approach using a combination of methods. The research location in the district of Bantul. Sources of data in this study are primary data and secondary data. Data collection techniques in this study using interview, questioner and documentation. The unit of data analysis in this study is the Social Security Agency. The sampling technique using the formula Slovin. Data analysis techniques in this study using data reduction, data presentation and conclusion. According to the research there is a relationship between BPJS with Health Facilities regulated in PP No.85 Year 2013 on cooperation in improving health services. Hospitals and health centers in collaboration with BPJS had been running quite positive. A total of 90 health facilities in Bantul who cooperate with BPJS. Of health insurance financing model thats enough ideal assessed on the index average of 2.74 included in either category. JKN one principle of mutual assistance means helping each one participant to the other participants. While the outcome JKN assessed on the percentage of the guarantee of health in Indonesia $(52.5 \%)$ in the province D.I.Y. (64.6\%) and in Bantul (73\%). Tinkat Bantul merepon public awareness by becoming participants BPJS. Service is guaranteed for the First level services and advanced stipulated in Presidential Decree No. 19 Year 2016. And the cost of minor health for the poor. Of the average index value JKN outcome of 3:06 categorized as either could mean that JKN program has considerable benefits for both participants.
\end{abstract}

Keywords: National Health Insurance, Health Policy and Evaluation JKN

\begin{abstract}
ABSTRAK
Pelayanan kesehatan adalah salah satu hak mendasar masyarakat yang diselenggarakan pemerintah sebagaimana telah diamanatkan dalam UUD 1945 Pasal 28 H Ayat (1) setiap orang berhak hidup sejahtera lahir batin, bertempat tinggal dan mendapat lingkungan hidup yang baik dan sehat serta berhak memperoleh pelayanan kesehatan. Badan Penyelenggara Jaminan Sosial terdiri dari BPJS Kesehatan dan BPJS Ketenagakerjaan yang nantinya mencakup seluruh penduduk Indonesia paling lambat 1 Januari 2019. Pelayanan BPJS Kesehatan banyak dipersoalkan masyarakat. Menurut Asisten ORI Perwakilan D.I.Y. Laporan keluhan prosedur pelayanan BPJS Kesehatan cukup tinggi pada tahun 2015. Keluhan masyarakat diantaranya dalam pengurusan birokrasi, pendaftaran, hingga antrian yang lama dan juga terkait pembayarannya. Dari permasalahan yang ada peneliti bertujuan untuk mengetahui pelaksanaan Jaminan Kesehatan Nasional (JKN) yang difokuskan pada Hubungan Stakeholder, Model Pembiayaan dan Outcome JKN di Kabupaten Bantul. Pendekatan penelitian ini menggunakan metode kombinasi. Lokasi penelitian di Kabupaten Bantul. Sumber data dalam
\end{abstract}


penelitian adalah data primer dan data sekunder. Teknik pengumpulan data dalam penelitian ini menggunakan metode wawancara, koesioner dan dokumentasi. Unit analisis data dalam penelitian ini adalah Badan Penyelenggara Jaminan Sosial. Teknik pengambilan sampel menggunakan rumus Slovin. Teknik analisis data dalam penelitian ini menggunakan reduksi data, penyajian data dan penarikan kesimpulan. Berdasarkan hasil penelitian ada hubungan antara BPJS dengan Fasilitas Kesehatan yang diatur dalam PP No.85 Tahun 2013 tentang kerja sama dalam meningkatkan pelayanan kesehatan. Rumah Sakit dan Puskesmas yang bekerja sama dengan BPJS selama ini berjalan cukup positif. Sebanyak 90 Fasilitas Kesehatan di Kabupaten Bantul yang bekerja sama dengan BPJS. Dari model pembiayaan asuransi kesehatan dirasa sudah cukup ideal yang dinilai dari indek rata-rata sebesar 2.74 termasuk dalam kategori baik. Prinsip JKN salah satunya gotong-royong yang berarti saling membantu satu perserta kepada peserta lain. Sedangkan dari outcome JKN yang dinilai dari persentase terjaminnya kesehatan di Indonesia (52.5\%) di provinsi D.I.Y. (64.6\%) dan di Kabupaten Bantul (73\%). Tinkat kesadaran masyarakat Kabupaten Bantul merepon positif dengan menjadi peserta BPJS. Pelayanan yang dijamin adalah pelayanan tingkat pertam dan tingkat lanjut yang diatur dalam Perpres No. 19 Tahun 2016. Dan biaya kesehatan yang ringan bagi masyarakat yang kurang mampu. Dari nilai indek rata-rata outcome JKN sebesar 3.06 masuk kategori baik yang bisa diartiakan bahwa program JKN mempunyai manfaat yang cukup baik bagi pesertanya.

Kata Kunci :Jaminan Kesehatan Nasional, Kebijakan Kesehatan dan Evaluasi JKN

\section{PENDAhUluan}

\section{A. Latar Belakang}

Pelayanan kesehatan adalah salah satu hak mendasar masyarakat yang penyediannya wajib diselenggarakan oleh pemerintah sebagaimana telah diamanatkan dalam Undang-undang Dasar 1945 pasal $28 \mathrm{H}$ ayat (1) Setiap orang berhak hidup sejahtera lahir dan batin, bertempat tinggal, dan mendapatkan lingkungan hidup yang baik dan sehat serta berhak memperoleh pelayanan kesehatan.

Pelayanan adalah suatu aktifitas yang bersifat tidak kasat mata (tidak dapat diraba) yang terjadi sebagai akibat adanya interaksi antara konsumen dengan kariawan atau hal-hal lain yang disediakan oleh perusahaan pemberi pelayanan yang dimaksudkan untuk memecahkan permasalahan konsumen atau pelanggan [1].

Berdasarkan Peraturan Presiden (Perpres) Nomor 19 Tahun 2016 tentang Perubahan Kedua atas Perpres Nomor 12 Tahun 2013 tentang Jaminan Kesehatan. Perubahan iuran jaminan kesehatan 
nasional untuk peserta pekerja bukan penerima upah dan peserta bukan pekerja. Perpres tentang naiknya iuran bagi para peserta Badan Penyelenggara Jaminan Sosial (BPJS) Kesehatan tersebut ditetapkan Presiden Joko Widodo pada 29 Februari 2016.

\section{Tabel I}

\section{Perubahan luran Jaminan Kesehatan Nasional Untuk Peserta Pekerja Bukan Penerima Upah dan Peserta Bukan Pekerja}

\begin{tabular}{lll}
\hline Ruang Perawatan & luran Lama & luran Baru \\
\hline Kelas I & Rp 59.500 & Rp 80.000 \\
\hline Kelas II & Rp 42.500 & Rp 51.000 \\
\hline Kelas III & Rp 25.500 & Rp 30.000 \\
\hline
\end{tabular}

\section{Sumber: Perpres 19 Tahun 2019}

Pemerintah membatalkan kenaikan iuran BPJS Kesehatan untuk kelas III yang diatur dalam Peraturan Presiden Nomor 19 Tahun 2016. Dalam Perpres tersebut, iuran BPJS Kesehatan untuk kelas III akan dinaikkan dari Rp 25.500 menjadi Rp 30.000. Setelah Pemerintah membatalkan kenaikan iuran BPJS Kesehatan maka besaran iuran yang dibayarkan bagi pemegang kartu kelas III sebesar Rp 25.500 [2].

Pelayanan Badan Penyelenggara Jaminan Sosial (BPJS) Kesehatan banyak yang dikeluhkan dan dipersoalkan masyarakat. Layanan Kesehatan milik pemerintah banyak dilaporkan kelembaga Ombudsman Republik Indonesia (ORI). Menurut Asisten ORI Perwakilan D. I. Yogyakarta (Bapak Jaka Susila Wahyuana) laporan keluhan tentang prosedur pelayanan BPJS Kesehatan cukup tinggi pada tahun 2015. Laporan yang masuk kelembaga Ombudsman Republik Indonesia (ORI) di antaranya dalam hal pengurusan 
14 birokrasi, pendaftaran, hingga antrian yang lama dan juga terkait pembayarannya [3].

Di Kabupaten Bantul yang mendaftar sebagai peserta anggota BPJS Kesehatan berjumlah 676.276 jiwa [4]. Kanit Ke uangan BPJS Kesehatan DIY Musdaliza menuturkan di tingkat kabupaten provinsi D. I. Yogyakarta yang membayar premi peserta BPJS Mandiri hanya $70 \%$ dari anggota yang tercat. Hal ini tentu berakibat lebih tinggi klaim yang dibayarkan oleh BPJS ke Rumah Sakit [5].

Ketidak seimbangan pembayaran melebihi angka $\mathrm{Rp} 1$ triliun. Jumlah iuran masuk hanya Rp 338 miliar, sementara jumlah klaim mencapai Rp 1.5 triliun. Penggunaan kartu secara tidak bijak disinyalir menjadi pemicu besarnya defisit yang harus ditanggung oleh BPJS Kesehatan [6].

Berdasarkan permasalahan-permasalahan tersebut serta melihat kenyataan yang terjadi di program asuransi kesehatan, maka peneliti tertarik untuk melakukan penelitian lebih lanjut dengan judul "Evaluasi Pelaksanaan Jaminan Kesehatan Nasional JKN (Studi Tentang Hubungan Stakeholder, Model Pembiayaan dan Outcome JKN di Kabupaten Bantul Provinsi Daerah Istimewa Yogyakarta 2016)".

\section{B. Rumusan Masalah}

Berdasarkan latar belakang di atas maka dirumuskan permasalahan sebagai berikut:

1. Bagaimana Hubungan Stakeholder dalam BPJS, Rumah Sakit, Puskesmas di Kabupaten Bantul ? 
2. Bagaimana Model Pembiayan BPJS Kesehatan di Kabupaten Bantul?

3. Apa Saja Outcome BPJS Kesehatan di Kabupaten Bantul bagi masyarakat?

C. Tujuan dan Manfaat

I. Tujuan Penelitian

Mengevaluasi pelaksanaan Jaminan Kesehatan Nasional (JKN), yaitu dari sisi Hubungan Antar Stakeholder, Model Pembiayan, dan Outcome di Kabupaten Bantul provinsi D. I. Yogyakarta.

Mengetahui secara mendalam pelaksanaan Jaminan Kesehatan Nasional (JKN), yaitu dari sisi Hubungan Antar Stakeholder, Model Pembiayaan dan Outcome di Kabupaten Bantul provinsi D. I. Yogyakarta.

2. Manfaat Penelitian

a. Manfaat Akademik

Hasil penelitian ini bermanfaat bagi para peneliti, mahasiswa dan semua pihak yang terkait untuk mengkaji tentang pelaksanaan Jaminan Kesehatan Nasional (JKN) di Kabupaten Bantul provinsi D. I. Yogyakarta.

\section{b. Manfaat Praktis}

Secara praktis penelitian ini diharapkan dapat bermafaat bagi kinerja Badan Penyelenggara Jaminan Sosial (BPJS) Kesehatan.

Dapat dijadikan bahan atau pedoman bagi pemerintah baik pusat maupun daerah dalam pengambilan kebijakan terkait dengan kinerja Badan Penyelenggara Jaminansial (BPJS) Kesehatan pada masa yang akan datang. 
76 D. Kajian Pustaka

Tabel 2

Ringkasan Hasil Penelitian Terdahulu

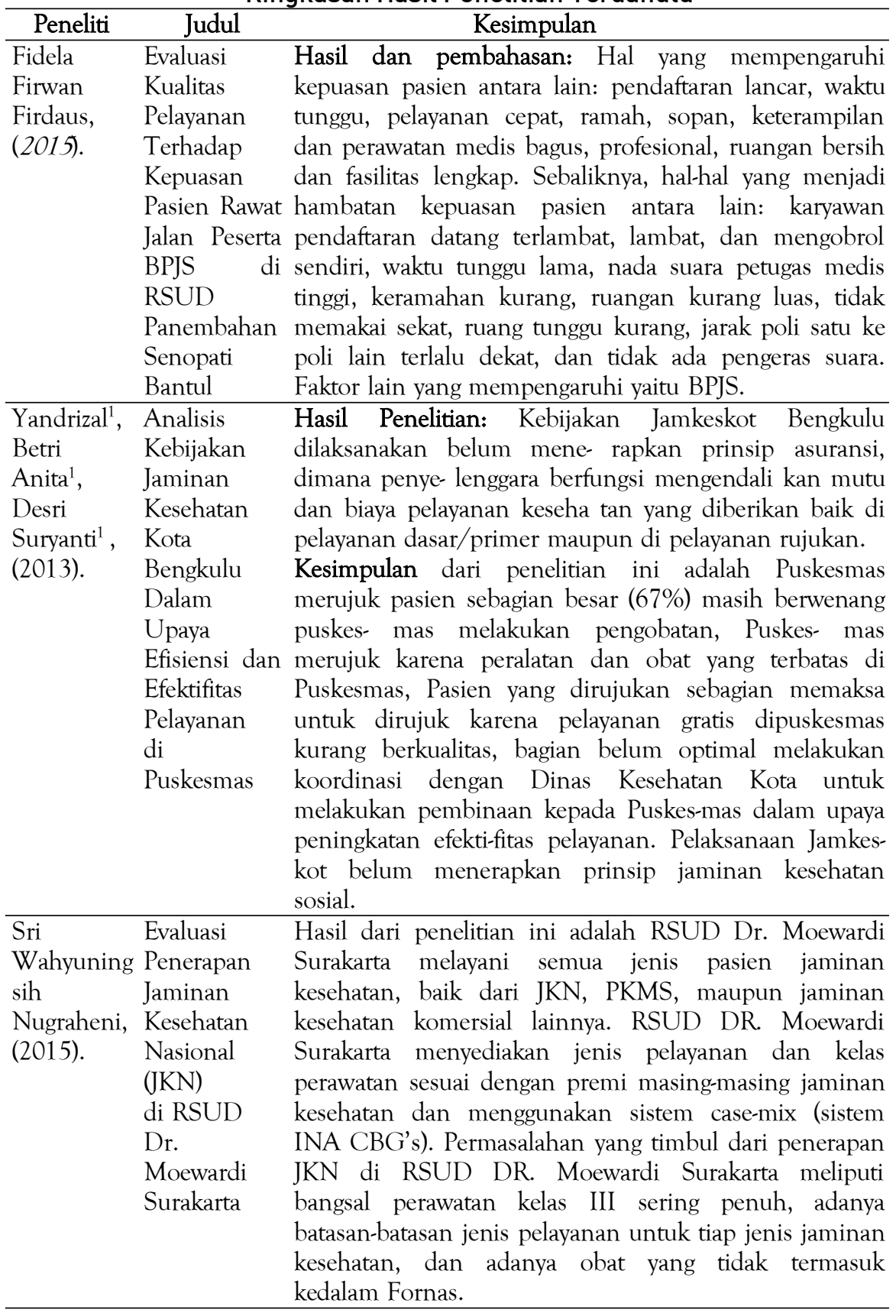


Bab I adalah pendahuluan. Dalam bab pendahuluan ini diuraikan latar belakang masalah, rumusan masalah, tujuan dan kegunaan penelitian.

Bab II adalah tinjauan pustaka dan landasan teori, kerangka pikir, defenisi konsep dan definisi operasinal serta variabel dan indikator penelitian.

Bab III adalah metode penelitian adalah tipe dan pendekatan, lokasi penelitian, jenis/sumber data, teknik pengumpulan data, unit analisi data, teknik pengambilan narasumber, teknik analisis data dan sistematika penulisan.

Bab IV adalah memuat deskripsi lokasi penelitian terdiri dari kondisi geografis, profil BPJS Kesehatan serta data-data pendukung lainnya.

Bab $\mathrm{V}$ adalah memuat tentang hasil dan analisis penelitian berupa Evaluasi Pelaksanaan Jaminan Kesehatan Nasional di Kabupaten Bantul yaitu dilihat dari Hubungan Stakeholder, Model Pembiayaan dan Outcome JKN bagi masyarakat.

Bab VI adalah mengakhiri keseluruhan pembahasan yang berisi kesimpulan dan saran.

\section{E. Landasan Teori}

1. Universal Health Coverage

Universal Health Coverage menurut [7] dapat diartikan sebagai cakupan menyeluruh. Istilah universal coverage berasal dari WHO (World Health Organisation), lebih tepatnya universal health 
coverage. menjelaskan lebih jauh lagi mengenai tiga dimensi universal health coverage yakni bahwa:

1. Dimensi cakupan kepesertaan

Dari dimensi ini universal coverage dapat diartikan sebagai "kepesertaan menyeluruh", dalam arti semua penduduk dicakup menjadi peserta jaminan kesehatan. Dengan menjadi peserta jaminan kesehatan diharapkan mereka memiliki akses terhadap pelayanan kesehatan. Namun tidak semua penduduk yang telah menjadi peserta jaminan kesehatan dapat serta merta mengakses pelayanan kesehatan. Jika di daerah tempat penduduk tinggal tidak ada fasilitas kesehatan, penduduk akan tetap sulit menjangkau pelayanan kesehatan.

2. Akses yang merata

Universal health coverage adalah akses yang merata bagi semua penduduk dalam memperoleh pelayanan kesehatan. Secara implisit pengertian ini mengandung implikasi perlu tersedianya fasilitas dan tenaga kesehatan agar penduduk yang menjadi peserta jaminan kesehatan benar-benar dapat memperoleh pelayanan kesehatan.

3. Pembiayaan yang ringan

Universal coverage juga berarti bahwa proporsi biaya yang dikeluarkan secara langsung oleh masyarakat (out of pocket payment) makin kecil sehingga tidak mengganggu keuangan peserta (financial catastrophic) yang menyebabkan peserta menjadi miskin.

Dari uraian-uraian tersebut di atas dapat disimpulkan bahwa semua masyarakat berhak mendapatkan pelayanan kesehatan, fasilitas kesehatan yang dibutuhkan tanpa ada kesulitan dan masyarakat tidak 
harus memikirkan bagaimanan cara membayarnya. Hal ini sesuai dengan kerangka konsep yang disebutkan oleh World Health Organization (WHO) bahwa "The WHO's conceptual framework suggests three broad dimensions of UHC: population coverage, service coverage, and financial coverage".

\section{Gambar 1}

Dimensi Universal Health Coverage

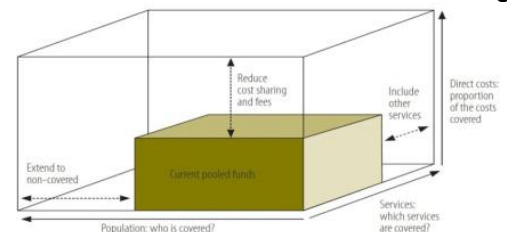

Sumber: WHO, The World Health Report (2010)

World Health Organization (WHO) menambahkan bahwa tiga dimensi dalam pencapaian universal health coverage yang digambarkan melalui kubus/gambar di atas. Ketiga dimensi universal health coverage dapat diterjemahkan sebagai berikut yaitu:

1. seberapa besar persentase penduduk yang dijamin, maksudnya yaitu jumlah penduduk yang dijamin.

2. seberapa lengkap pelayanan yang dijamin maksudnya layanan kesehatan yang dijamin apakah hanya layanan di rumah sakit atau termasuk juga layanan rawat jalan.

3. seberapa besar proporsi biaya langsung yang masih ditanggung oleh penduduk maksudnya semakin banyak dana yang disediakan, maka semakin banyak pula penduduk yang terlayani, sehingga semakin komprehensif paket pelayanannya serta semakin kecil proporsi biaya yang harus ditanggung oleh penduduk. 


\section{Pengertian Lembaga}

Menurut [8] aturan dan rambu-rambu sebagai panduan yang dipakai oleh para anggota suatu kelompok masyarakat untuk mengatur hubungan yang saling mengikat atau saling tergantung satu sama lain. Penataan institusi (institutional arrangements) dapat ditentukan oleh beberapa unsur: aturan operasional untuk pengaturan pemanfaatan sumber daya, aturan kolektif untuk menentukan, menegakan hukum atau aturan itu sendiri dan untuk merubah aturan operasional serta mengatur hubungan kewenangan organisasi.

Berdasarkan defenisi diatas dapat disimpulkan bahwa lembaga adalah suatu konsep pola perilaku sosial yang sudah berlangsung secara terus menerus dan peraturan suatu lembaga yang berprinsif pada norma-norma yang positif.

Schmid North mengartikan kelembagaan sebagai sejumlah peraturan yang berlaku dalam sebuah masyarakat, kelompok atau komunitas, yang mengatur hak, kewajiban, tanggung jawab, baik sebagai individu maupun sebagai kelompok. Menurut Schotter kelembagaan merupakan regulasi atas tingkah laku manusia yang disepakati oleh semua anggota masyarakat dan merupakan penata interaksi dalam situa tertentu yang berulang [9].

\section{Stakeholder}

Menurut [10] stakeholder theory mengatakan bahwa perusahaan bukanlah entitas yang hanya beroperasi untuk kepentingannya sendiri namun harus memberikan manfaat bagi stakeholdernya (shareholders, kreditor, konsumen, supplier, pemerintah, masyarakat, analis dan pihak lain). Dengan demikian, 
keberadaan suatu perusahaan sangat dipengaruhi oleh dukungan yang diberikan oleh stakeholder kepada perusahaan tersebut.

Menurut [11] memperkenalkan konsep stakeholder dalam dua model yaitu:

1.Model kebijakan dan perencanaan bisnis

Model pertama, fokusnya adalah mengembangkan dan mengevaluasi persetujuan keputusan strategis perusahaan dengan kelompok-kelompok yang dukungannya diperlukan untuk kelangsungan usaha perusahaan. Dapat dikatakan bahwa, dalam model ini, stakeholder theory berfokus pada cara-cara yang dapat digunakan oleh perusahaan untuk mengelola hubungan perusahaan dengan stakeholder-nya.

2.Model tanggung jawab sosial perusahaan dari manajemen stakeholder

Sementara dalam model kedua, perencanaan perusahaan dan analisis diperluas dengan memasukkan pengaruh eksternal yang mungkin berlawanan bagi perusahaan. Kelompok-kelompok yang berlawanan ini termasuk badan regulator (government) dengan kepentingan khusus yang memiliki kepedulian terhadap permasalahan sosial.

4. Pembiayaan Kesehatan

Konsep biaya dalam bahasa Inggris biasa menggunakan istilah cost, financial, expenditure. Biaya menurut [12] adalah sebagai cost as an exchange, a forgoing made to secure benefit. Cost sinonim dengan expense yang digunakan untuk mengukur pengeluaran (outflow) 
82 barang atau jasa yang disandingkan dengan pendapatan untuk mengukur pendapatan.

1. Definisi pembiayaan kesehatan

Yang dimaksud dengan pembiayaan adalah besarnya dana yang harus disediakan untuk menyelanggarakan dan atau memanfaatkan berbagai upaya kesehatan yang diperlukan oleh perorangan, keluarga, kelompokdan masyarakat [13]. Pembiayaan kesehatan harus stabil dan selalu berkesinambungan untuk menjamin terselenggaranya kecukupan (adequacy), pemerataan (equity), efisiensi (efficiency), dan efektifitas (effectiveness) pembiayaan kesehatan itu sendiri.

Pengertian pembiayaan tersebut merujuk pada dua sudut pandang berikut:

1) Penyedia Pelayanan Kesehatan (health provider) adalah besarnya dana yang harus disediakan untuk dapat menyelenggarakan upaya kesehatan.

2) Pemakaian jasa pelayanan (health consumer) adalah besarnya dana yang harus disediakan untuk dapat memanfaatkan jasa pelayanan.

Jenis-jenis pembiayaan kesehatan dilihat dari pembagian pelayanan kesehatan tersendiri atas :

1) Biaya pelayanan kedokteran yaitu biaya untuk menyelenggarakan dan/atau memanfaatkan pelayanan kedokteran yang tujuan utamanya mengarah ke pengobatan dan pemulihan dengan sumber dana dari sektor pemerintah maupun swasta. 
2) Biaya pelayanan kesehatan masyarakat yaitu biaya untuk menyelenggarakan dan/atau memanfaatkan pelayanan kesehatan masyarakat yang tujuan utamanya mengarah ke peningkatan kesehatan dan pencegahan dengan sumber dana terutama dari sektor pemerintah.

5. Outcome Program Jaminan Kesehatan Nasional - JKN

Outcome adalah hasil nyata dari autput suatu kegitan dan merupakan ukuran kinerja dari suatu program dalam memenuhi sasarannya. Outcome adalah tolak ukur kinerja berdasarkan tingkat keberhasilan yang akan dicapai berdasarkan tujuan program atau kegiatan yang sudah dilaksanakan.

6. Evaluasi Kebijakan Publik

Menurut [14] Evaluasi dilakukan karna tidak semua program kebijakan publik meraih hasil yang diinginkan. Secara umum evaluasi kebijakan dapat dikatakan sebagai kegiatan yang menyangkut estemasi atau penilaian kebijakan yang mencakup subtansi, implementasi dan dampak.

Tugas pertama adalah untuk menentukan kosekuensikosekuensi apa yang ditimbulkan oleh suatu kebijakan dengan cara menggambarkan dampaknya. Tugas kedua adalah untuk menilai keberhasilan atau kegagalan dari suatu kebijakan berdasarkan standard atau kriteria yang telah ditetapkan sebelumnya. Tugas kedua dalam evaluasi kebijakan pada dasarnya berkait erat dengan tugas yang pertama.

Dari kedua hal yang dipaparkan diatas, maka kita dapat menarik suatu kesimpulan mengenai arti pentingnya evaluasi dalam 
kebijakan pubik. Pengetahuan menyangkut sebab-sebab kegagalan suatu kebijakan dalam meraih dampak yang diinginkan dapat dijadikan pedoman untuk mengubah atau memperbaiki kebijakan di masa yang akan datang.

Tabel 3

Model Evaluasi

\begin{tabular}{|l|l|}
\hline Tipe Kriteria & Pertanyaan \\
\hline Efektifitas & Apakah hasil yang diinginkan telah tercapai? \\
\hline Efisiensi & Berapa banyak dipergunakan sumber daya? \\
\hline Kecukupan & $\begin{array}{l}\text { Seberapa jauh pencapaian hasil yang diinginkan } \\
\text { telah memecahkan masalah? }\end{array}$ \\
\hline $\begin{array}{l}\text { Peralatan } \\
\text { (equity) }\end{array}$ & $\begin{array}{l}\text { Apakah biaya dan mafaat didistribusikan dengan } \\
\text { merata pada kelompok target yang berbeda? }\end{array}$ \\
\hline Responsivitas & $\begin{array}{l}\text { Apakah hasil kebijakan memuaskan kebutuhan, } \\
\text { preferensi, atau nilai kelompok-kelompok tertentu? }\end{array}$ \\
\hline ketepatan & $\begin{array}{l}\text { Apakah hasil yang diinginkan benar-benar berguna } \\
\text { atau bernilai? }\end{array}$ \\
\hline
\end{tabular}

Menurut [15] evaluasi adalah menentukan pada penciptaan premis-premis nilai dengan kebutuhan untuk menjawab pertanyanan: “apa perbedaan yang dibuat?" kriteria untuk evaluasi diterapkan secara restrospektif (ex post), sementara kriteria untuk rekomendasi diterapkan secara prospektif (ex ante). Kriteria kebijakan sama dengan kriteria rekomendasi kebijakan, yang dijabarkan pada tabel 3 di atas.

\section{METODE PENELITIAN}

\section{A. Tipe dan Pendekatan}

Penelitian ini menggunakan metode kombinasi (Mixed Methods). [16] metode penelitian kombinasi merupakan pendekatan dalam penelitian yang mengkombinasikan atau menghubungkan 
antara metode penelitian kuntitatif dan kualitatif. Hal itu mencakup landasan filosofis, penggunaan pendekatan kulitatif dan kuantitatif, dan mengombinasikan kedua pendekatan dalam penelitian.

\section{B. Teknik Pengumpulan Data}

Data dan informasi dikumpulkan melalui wawancara, koesioner serta dokumentasi dengan masalah yang di teliti seperti uraian dibawah:

1. Wawancara adalah tanya jawab antara peneliti dengan responden. Wawancara dimaksudkan untuk mendapatkan data secara detail dari responden terkait dengan permasalahan yang di teliti.

2. Koesioner (Angket) merupakan teknik pengumpulan data yang dilakukan dengan cara memberi seperangkat pertanyaan dan pernyataan tertulis kepada responden alternatif jawaban: sangat setuju (SS), setuju (S), tidak setuju (TS), dan sangat tidak setuju (STS). Pengukuran dengan menggunakan skala likert, menurut [17] skala likert digunakan untuk mengukur sikap, pendapat dan persepsi seseorang atau sekelompok orang tentang fenomena sosial. Skala ini menggunakan respon yang dikategorikan dalam empat macam kategori jawaban dengan bobot penilaian:

1) Alternatif jawaban Sangat Setuju (SS) diberi nilai 4

2) Alternatif jawaban Setuju (S) diberi nilai 3

3) Alternatif jawaban Tidak Setuju (TS) diberi nilai 2

4) Alternatif jawaban Sangat Tidak Setuju (STS) diberi nilai 1 
Analisis data kuantitatif merupkan pengukuran yang digunakan dalam suatu penelitian yang dapat dihitung dengan jumlah satuan tertentu atau dinyatakan dalam angka-angka. Analisis ini meliputi pengolahan data, pengorganisasian data, dan penemuan hasil. Dalam penelitian ini, analisis data kuantitatif yang digunakan adalah analisis angka indeks. Analisis indeks tersebut ditentukan dengan menggunakan rumus sebagai berikut:

$$
P=F / N \times 100 \%
$$

Keterangan :

$$
\begin{aligned}
& \mathrm{P}=\text { Presentase } \\
& \mathrm{F}=\text { Frekuensi atau banyaknya jawaban } \\
& \mathrm{N}=\text { jumlah responden }
\end{aligned}
$$

Sehingga untuk mengetahui tingkat evaluasi pelaksanaan Jaminan Kesehatan Nasional-JKN di Kabupaten Bantul menggunakan skala indeks dengan rumus :

$$
\underline{\left(f_{S S} \times 4\right)+\left(f_{S} \times 3\right)+\left(f_{T S} \times 2\right)+\left(f_{S T S} \times 1\right)}
$$

$\mathrm{N}$

Keterangan :

$\mathrm{N}=$ Jumlah sampel

$\mathrm{F}_{\mathrm{SS}}=$ Frekuensi yang menjawab option $\mathrm{ss}$

$\mathrm{F}_{\mathrm{S}}=$ Frekuensi yang menjawab option $\mathrm{s}$

$\mathrm{F}_{\mathrm{TS}}=$ Frekuensi yang menjawab option $\mathrm{TS}$

$\mathrm{F}_{\mathrm{STS}}=$ Frekuensi yang menjawab option sTS

Analisis deskriptif variabel merupakan gambaran variabel yang diperoleh berdasarkan jawaban responden mengenai pertanyaan atau 
pernyataan yang didasarkan pada indikator yang akan diteliti. Kecenderungan jawaban responden akan dilihat untuk semua variabel penelitian. Kategori masing-masing variabel ditentukan dengan terlebih dahulu membuat interval kelas dengan rumus:

Keterangan kategori berdasarkan perhitungan interval kelas tersebut, dapat dilihat pada Tabel III.3

Tabel III.3

\section{Kategori Interpretasi}

\begin{tabular}{|l|l|}
\hline Kategori & Range \\
\hline Sangat Baik & $3,26-4,00$ \\
\hline Baik & $2,51-3,25$ \\
\hline Kurang Baik & $1,76-2,50$ \\
\hline Tidak Baik & $1,00-1,75$ \\
\hline
\end{tabular}

Berdasarkan kategori pada Tabel III.3 variabel dalam penelitian ini akan ditentukan dengan cara menghitung mean untuk setiap variabel penelitian dan hasilnya akan dicocokkan masuk dalam kategori yang mana dari tabel interpretasi diatas.

3. Dokumentasi adalah mengumpulkan data dengan cara mencacat atau mengkutip dari dokumen atau arsip-asrip berupa regulasi, majalah, internet yang diperlukan untuk melengkapi data.

\section{Tekhnik Analisa Data}


Menurut [18] analisa data kualitatif adalah upaya yang dilakukan dengan jalan berkerja dengan data, mengorganisasikan data, memilah-milahnya menjadi suatu yang dapat dikelola, mengsintesiskannya, mencari dan menemukan pola, menemukan apa yang penting dan apa yang dipelajari, dan memutuskan apa yang dapat diceritakan kepada orang lain.

1. Reduksi Data

Merupakan proses seleksi, pemfokusan, penyederhanaan, abstraksi data yang kasar yang dilaksanakan dalam penelitian dan mengatur sedemikian rupa sehingga dapat ditarik kesimpulan.

2. Penyajian Data

Sajian singkat adalah suatu rakitan organisasi informasi yang memungkinkan kesimpulan penelitian dilakukan. Dengan melihat suatu penyajian data, peneliti akan mengerti apa yang akan terjadi dan memungkinkan untuk mengerjakan suatu analisa atau suatu tindakan lain berdasarkan tindakan tersebut.

3. Penarikan kesimpulan

Dalam kegiatan ini, peneliti melakukan kegiatan penarikan kesimpulan dari hasil penelitian. Akan tetapi kesimpulan itu masih bersifat sementara sampai penelitian berakhir baru dapat diambil kesimpulan yang sesungguhnya.

\section{HASIL DAN PEMBAHASAN}

\section{A. Hubungan Stakeholder}


1. Hubungan Kerja Sama Badan Penyelenggara Jaminan Sosial (BPJS) Dengan Rumah Sakit

Badan Penyelenggara Jaminan Sosial (BPJS) adalah badan hukum publik yang dibentuk untuk menyelenggarakan program jaminan sosial. BPJS terdiri dari BPJS Kesehatan dan BPJS Ketenagakerjaan. Sedangkan BPJS Kesehatan adalah badan hukum yang dibentuk untuk menyelenggarakan program jaminan kesehatan.

Rumah sakit adalah salah satu bagian pelayanan kesehatan yang dikembangkan dalam membangun kesehatan. Kebutuhan akan kesehatan menjadi bagian yang sangat vital membuat rumah sakit menjadi sangat penting.

Rumah sakit menurut [19] yaitu suatu bagian menyeluruh, (Integrasi) dari organisasi dan medis, berfungsi memberikan pelayanan kesehatan lengkap kepada masyarakat baik kuratif maupun rehabilitatif, dimana output layanannya menjangkau pelayanan keluarga dan lingkungan, rumah sakit juga merupakan pusat pelatihan tenaga kesehatan serta untuk penelitian biososial.

Dari tabel 4 di halaman berikutnya tampak bahwa jumlah Rumah Sakit yang bekerja sama dengan BPJS Kesehatan Provinsi D. I. Yogyakarta berjumlah 57 Rumah Sakit. Jumlah ini terbagi atas Kabupaten yang ada di provinsi Daerah Istimewa Yogyakarta. Sedangkan di Kabupaten Bantul jumlah Rumah Sakit yang bekerja sama dengan BPJS Kesehatan berjumlah 13 Rumah Sakit.

Tabel 4

Daftar Faskes II di Wilayah/Kabupaten Yang Bekerja Sama Dengan BPJS Provinsi DIY

\begin{tabular}{|l|l|l|}
\hline No & Wilayah/Kabupaten & Jumlah Faskes II \\
\hline
\end{tabular}




\begin{tabular}{|l|l|l|}
\hline 1 & Kabupaten Bantul & 13 \\
\hline 2 & Kabupaten Gunung Kidul & 3 \\
\hline 3 & Kabupaten Kulon Progo & 4 \\
\hline 4 & Kabupaten Sleman & 21 \\
\hline 5 & Kota Yogyakarta & 16 \\
\hline \multicolumn{2}{|l}{ Jumlah } & $\mathbf{5 7}$ \\
\hline
\end{tabular}

Sumber: Data Diolah Peneliti BPJS-Kesehatan

2. Hubungan Kerja Sama Badan Penyelenggara Jaminan Sosial (BPJS) Dengan Puskesmas

Badan Penyelenggara Jaminan Sosial adalah badan hukum publik yang dibentuk untuk menyelenggarakan program jaminan sosial. BPJS terdiri dari BPJS Kesehatan dan BPJS Ketenagakerjaan.

Pusat Kesehatan Masyarakat (Puskesmas) adalah salah satu pelaksana pelayanan kesehatan masyarakat yang sangat penting di Indonesia. Pusat pembinaan masyarakat di bidang kesehatan dan pelayanan kesehatan tingkat pertama yang unit pelaksana teknis dinas kebupaten/kota yang bertanggungjawab menyelenggarakan pembangunan kesehatan di suatu wilayah kerja (Depkes, 2011).

Puskesmas adalah unit pelayanan tingkat pertama dalam membangun kesehatan di Indonesia. Pelayanan tingkat pertama ini menjadi sangat penting keberadaaya untuk mewujudkan derajat kesehatan secara optimal.

Tabel 5

Daftar Faskes I di Wilayah/Kabupaten

Yang Bekerja Sama Dengan BPJS Provinsi DIY 


\begin{tabular}{|c|c|c|}
\hline No & Wilayah/Kabupaten & $\begin{array}{c}\text { Jumlah Faskes } \\
\text { I }\end{array}$ \\
\hline 1 & Kabupaten Bantul & 27 \\
\hline 2 & Kabupaten Gunung Kidul & 30 \\
\hline 3 & Kabupaten Kulon Progo & 21 \\
\hline 4 & Kabupaten Sleman & 25 \\
\hline 5 & Kota Yogyakarta & 18 \\
\hline \multicolumn{2}{|c|}{ Jumlah } & $\mathbf{1 2 1}$ \\
\hline
\end{tabular}

Sumber: Data Diolah Peneliti BPJS-Kesehatan

Dari tabel diatas tampak bahwa jumlah Puskesmas yang bekerja sama dengan BPJS Kesehatan Provinsi D. I. Yogyakarta bejumlah 121 puskesmas. Jumlah ini terbagi atas Kabupaten yang ada di provinsi Daerah Istimewa Yogyakarta. Sedangkan di Kabupaten Bantul jumlah Puskesmas dan Rumah Sakit yang bekerja sama dengan BPJS Kesehatan berjumlah 27 Puskemas. Kabupaten Bantul terbanyak kedua dari Kabupaten Gunung Kidul dalam hubungan kerja sama BPJS Kesehatan dengan fasilitas kesehatan tingkat pertama.

Dari tabel 6 di halaman berikut tampak bahwa jumlah yang terbanyak di fasilitas kesehatan Pusat Kesehatan Masyarakat sebesar 27 fasilitas kesehatan dan yang paling sedikit di fasilitas Kesehatan RS TNI/POLRI, Fasilitas Kesehatan Klinik POLRI sebesar 1 fasilitas kesehatan. Dari jumlah keselurhan sebesar 90 fasilitas kesehatan yang ada di Kabupaten Bantul. 


\begin{tabular}{|l|l|l|}
\hline No & Nama Fasilitas Kesehatan & Jumlah \\
\hline 1 & Fasilitas Kesehatan Rumah Sakit & 13 \\
\hline 2 & Fasilitas Kesehatan RS TNI/POLRI & 1 \\
\hline 3 & Fasilitas Kesehatan Puskesmas & 27 \\
\hline 4 & Fasilitas Kesehatan Dokter Praktik Perorangan & 13 \\
\hline 5 & Fasilitas Kesehatan Dokter Gigi & 6 \\
\hline 6 & Fasilitas Kesehatan Klinik Pratama & 8 \\
\hline 7 & Fasilitas Kesehatan Klinik TNI & 3 \\
\hline 8 & Fasilitas Kesehatan Klinik POLRI & 1 \\
\hline 9 & Fasilitas Kesehatan Apotek & 13 \\
\hline 10 & Fasilitas Kesehatan Optik & 2 \\
\hline 11 & Fasilitas Kesehatan Lainnya & 3 \\
\hline Jumlah Fasilitas Kesehatan & 90 \\
\hline
\end{tabular}

Sumber: Data Diolah Peneliti BPJS-Kesehatan

a. Pola hubungan antar lembaga Bandan Penyelenggara Jamaian Sosial (BPJS) Kesehatan dengan Fasilitas Kesehatan

Hubungan Kerja Sama antar lembaga Badan Penyelenggara Jaminan Sosial (BPJS) dengan Faslitas Kesehatan yang telah diamanatkan dalam Peraturan Pemerintah RI Nomor 85 Tahun 2013 Pasal 6 ayat 1 dan 2 Badan Penyelenggara Jaminan Sosial (BPJS) dalam melaksanakan tugasnya, dapat melakukan kerja sama dengan organisasi atau lembaga lain dalam negeri dan luar nergi. Kerja sama ini dilakukan dalam rangka meningkatkan kualitas BPJS Kesehatan atau meningkatkan kualitas pelayanannya kepada peserta. 
Badan Penyelenggara Jaminan Sosial adalah badan hukum publik yang dibentuk untuk menyelenggarakan program jaminan sosial. BPJS terdiri dari BPJS Kesehatan dan BPJS Ketenagakerjaan.

Menurut Peraturan Presiden No. 19 Tahun 2016 tentang perubahan kedua atas Peraturan Presiden No.12 Tahun 2013 Tentang Jaminan Kesehatan dalam pasal 1 ayat 14 menjelaskan bahwa pengertian dari fasilitas kesehatan ialah pelayanan kesehatan yang digunakan untuk menyelenggarakan upaya pelayanan kesehatan perorangan, baik promotif, preventif, kuratif maupun rehabilitatif yang dilakukan oleh Pemerintah, Pemerintah Daerah, dan/atau Masyarakat.

Fasilitas kesehatan haruslah menjamin kesehatan dari pesertanya sendiri. Menurut peraturan presiden tersebut, setidaknya ada dua kategori yang masuk kepada peserta JKN Kesehatan yaitu, PBI dan bukan PBI kesehatan. Peserta PBI kesehatan adalah orang yang tergolong fakir miskin dan tidak mampu. Sedangkan peserta bukan PBI kesehatan merupakan pesrta yang bukan tergolong fakir miskin dan orang yang tidak mampu, diantaranya ialah pekerja penerima upah dan kelurganya, pekerja bukan penerima upah dan keluarganya, serta bukan pekerja dan angota keluarganya.

Adapun pekerja penerima upah yang dimaksud ialah pegawai negeri sipil (PNS), anggota TNI, anggota Polri, pejabat negara, pegawai pemerintah non pegawai negeri, pegawai swasta, dan pekerja yang tak termasuk jenis-jenis pekerjaan diatas namun menerima upah. Sedangkan pekerja bukan penerima upah yang dimaksud ialah pekerja diluar interaksi kerja atau pekerja mandiri ataupun pekerjaan lainnya yang bukan penerima upah. 
Fasiltas kesehatan memberikan pelayanan kesehatan terhadap perserta BPJS Kesehatan dalam rangka memenuhi kebutuhan derajat kesehatan bagi seluruh lapisan masyarakat tanpa membeda-bedakan ras, suku, bangsa.

3. Alur Pelayanan Peserta BPJS Kesehatan

Alur pelayanan peserta BPJS Kesehatan melalui beberapa tahapan yang dijelaskan dalam gambar V.2 adalah:

\section{Gambar 2}

Alur Pelayanan Kesehatan

Alur Pelayanan Kesehatan

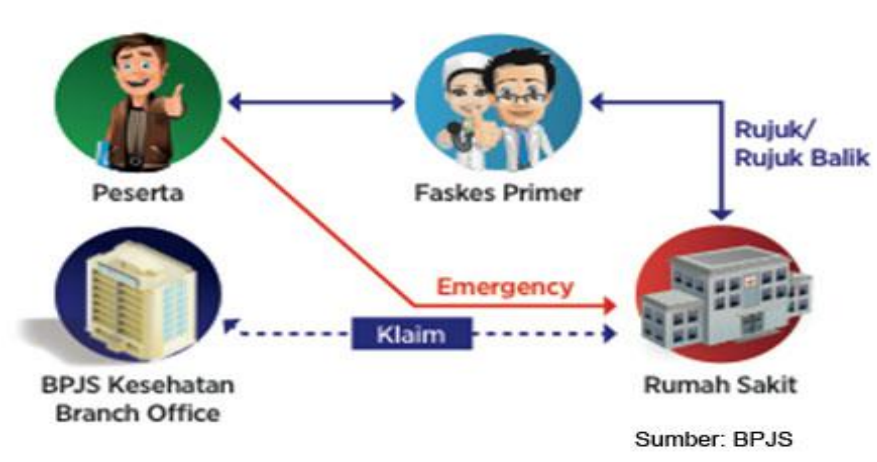

\section{B. Model Pembiayaan Asurasi BPJS Kesehatan}

1. Pembiayaan Peserta BPJS Kesehatan

Iuran Jaminan Kesehatan adalah sejumlah uang yang dibayarkan secara teratur oleh Peserta, Pemberi Kerja, dan/atau Pemerintah untuk program Jaminan Kesehatan (pasal 16, Perpres No. 19/2016 tentang perubahan kedua atas Perpres No. 12/2013 tentang Jaminan Kesehatan). 
Tebel 7

Besaran luran Yang Harus Dibayar Peserta JKN

\begin{tabular}{|c|c|c|c|}
\hline PESERTA & $\begin{array}{l}\text { BENTUK } \\
\text { IURAN }\end{array}$ & BESARAN IURAN & KET \\
\hline PBI & $\begin{array}{l}\text { Nilai Nominal } \\
\text { (per jiwa) }\end{array}$ & $\begin{array}{l}\text { Mulai } 1 \text { Januari } 2016 \\
\text { Rp. } 23.000 \text { (dibayarkan } \\
\text { oleh pemerintah) }\end{array}$ & $\begin{array}{l}\text { Rawat inap kelas } \\
3\end{array}$ \\
\hline $\begin{array}{l}\text { PNS/TNI/P } \\
\text { OLRI/ } \\
\text { PENSIUN }\end{array}$ & $\begin{array}{l}5 \% \\
\text { (perkeluarg) }\end{array}$ & $\begin{array}{l}2 \% \text { dari pekerja } \\
3 \% \text { dari pemeberi kerja }\end{array}$ & $\begin{array}{l}\text { Rawat Inap Kelas } \\
1 \\
\text { Kelas } 2\end{array}$ \\
\hline $\begin{array}{l}\text { Pekerja } \\
\text { Penerima } \\
\text { Upah } \\
\text { Selain } \\
\text { PNS dll }\end{array}$ & $\begin{array}{l}4,5 \% \\
\text { (per } \\
\text { keluarga) } \\
\text { Dan } \\
5 \% \\
\text { (per keluarga) }\end{array}$ & $\begin{array}{l}\text { s/d } 30 \text { juni } 2015 \text { : } \\
\text { 0,5\% dari pekerja } \\
\text { 4\% dari pemberi kerja } \\
\text { Mulai } 1 \text { juli } 2015 \text { : } \\
\text { 1\% dari pekerja } \\
\text { 4\% dari pemberi kerja }\end{array}$ & $\begin{array}{l}\text { Rawat inap kelas } \\
1 \text {, kelas } 2\end{array}$ \\
\hline $\begin{array}{l}\text { Pekerja } \\
\text { Bukan } \\
\text { Penerima } \\
\text { Upah dan } \\
\text { Bukan } \\
\text { Pekerja }\end{array}$ & $\begin{array}{l}\text { Nilai nominal } \\
\text { (per jiwa) }\end{array}$ & $\begin{array}{l}\text { Mulai } 1 \text { April } 2016 \text { : } \\
\text { 1. Rp. } 30.000 \\
\text { 2. Rp. } 51.000 \\
\text { 3. Rp. } 80.000\end{array}$ & $\begin{array}{l}\text { 1. Rawat inap kelas } \\
3 \\
\text { 2. Rawat inap kelas } \\
2 \\
\text { 3. Rawat inap kelas } \\
1\end{array}$ \\
\hline
\end{tabular}

Sumber: Perpres No 19 Tahun 2016

a. Model pembiayaan BPJS kesehatan

Ringkasan variabel model pembiayaan BPJS kesehatan dijelaskan dalam tabel V.9 adalah : 


\section{Tabel 8}

Ringkasan Variabel Model

Pembiayaan BPJS Kesehatan

\begin{tabular}{|l|l|l|l|}
\hline No & Indikator & Nilai Indeks & Ket \\
\hline 1 & $\begin{array}{l}\text { Besaran iuran memberatkan } \\
\text { peserta BPJS Kesehatan }\end{array}$ & 2.04 & Kurang Baik \\
\hline 2 & $\begin{array}{l}\text { Pembayaran iuran sesuai } \\
\text { manfaat yang diterima peserta } \\
\text { BPJS Kesehatan }\end{array}$ & 3.04 & Baik \\
\hline 3 & $\begin{array}{l}\text { Kemudahan sistem pembayaran } \\
\text { BPJS Kesehatan }\end{array}$ & 2.95 & Baik \\
\hline 4 & $\begin{array}{l}\text { Kemudahan penggunaan BPJS } \\
\text { Kesehatan }\end{array}$ & 2.91 & Baik \\
\hline Nilai Indeks Rata-Rata & $\mathbf{2 . 7 4}$ & Baik \\
\hline
\end{tabular}

Sumber: Data Diolah Peneliti Hasil Penelitian

Dari penjelasan diatas, dari nilai indek rata-rata indikator yang ada pada tabel V.9 sebesar 2.74 masuk kedalam kategori Baik. Niali ini dapat diartikan bahwa masyarakat di Kabupaten Bantul memiliki persepsi dengan model pembiayaan BPJS Kesehatan saat ini cukup ideal.

2. Skema Pembayaran BPJS Kesehatan Kepada Rumah Sakit

Sedangkan untuk fasilitas rujukan tingkat lanjut, BPJS Kesehatan membayar dengan sistem paket INA-CBG's.

Berdasarkan tabel 9 klaim dari rumah sakit kepada pihak BPJS Kesehatan persatu bulan berdasarkan uraian diantaranya pelayanan kesehatan Rawat Ianap Tingkat Lanjut (RITL) sebesar 4.491.627.109 dan Rawat Jalan Tingkat Lanjut (RJTL) sebesar 3.365.370.400 total sebesar 7.856.997.509 yang harus dibayarkan dari pihak BPJS Kesehatan kepada rumah sakit. 
Tabel 9

Komfirmasi Pembayaran BPJS Kesehatan Kepada RSUD

Panembahan Senopati Tanggal 21 Juli 2016

\begin{tabular}{|l|l|l|l|l|l|}
\hline NO & NAMA PPK & URAIAN & BANK & $\begin{array}{l}\text { NOMOR } \\
\text { REKENING }\end{array}$ & $\begin{array}{l}\text { JUMLAH } \\
\text { RP. }\end{array}$ \\
\hline \multirow{3}{*}{1} & $\begin{array}{l}\text { RSUD } \\
\text { Panembahan } \\
\text { Senopati }\end{array}$ & RITL Mei'16 & mandiri & 1370005341884 & 4.491 .627 .109 \\
\cline { 2 - 5 } & RJTL Mei'16 & & & 3.365 .370 .400 \\
\cline { 2 - 6 } & Biaya Transfer & & & - \\
\hline \multicolumn{4}{|l|}{ Jumlah Ditransfer } & & 7.856 .997 .509 \\
\hline
\end{tabular}

Sumber: RSUD Penembahan Sinopati Bantul

3. Skema Pembayaran BPJS Kesehatan Kepada Puskesmas

pembayaran BPJS Kesehatan kepada fasiliatas kesehatan tingkat pertama dengan kapitasi.

Tabel 10

Komfirmasi Pembayaran Kapitasi BPJS Kesehatan

Kepada Puskesmas Bantul 1 Tanggal 15 Juni 2016

\begin{tabular}{|c|c|c|c|c|c|c|c|}
\hline NO & NAMA FKTP & $\begin{array}{l}\text { TOTAL } \\
\text { PESERTA }\end{array}$ & $\begin{array}{l}\text { BPJ } \\
\text { hEI }\end{array}$ & $\begin{array}{l}\text { BPJ } \\
\text { APRIL }\end{array}$ & $\begin{array}{l}\text { OTAL } \\
\text { KAPITASI }\end{array}$ & PAJAK & $\begin{array}{l}\text { JUMLAH } \\
\text { DITRASFER }\end{array}$ \\
\hline 1 & $\begin{array}{l}\text { Puskesmas Bantul } \\
1\end{array}$ & 3.489 & .000 & 6.000 & 40.934 .00 & & 40.934 .000 \\
\hline & & & & & & & \\
\hline & iava Transfer & & & & & & \\
\hline \multicolumn{7}{|c|}{ Jumlah } & 140.929 .000 \\
\hline
\end{tabular}

Sumber: Puskesmas Bantul 1

Berdasarkan hasil tabel diatas klaim dari puskesmas bantul 1 kepada pihak BPJS Kesehatan persatu priode pembayaran pada bulan Mei peserta yang terbagi dalam status keanggotaannya diantaranya, 
98 peserta dengan status Non PBI sebanyak 7.574 jiwa dan peserta dengan status PBI sebanyak 15.880 jiwa dan jumlah keseluruhan peserta pada bulan Mai 2016 sebesar 23.454 jiwa. Dari setiap peserta BPJS Kesehatan nilai nominal yang dibayarkan sebesar 6.000 rupiah dan jumlah keseluruhan kapitasi pada bulan mai sebesar 140.724.000. Dan terdapat peserta susulan pada bulan April 2016 sebanyak 35 orang peserta, jumlah kapitasi susulan sebesar 210.000. dari jumlah peserta keseluruhan yang berobat pada bulan mai dan peserta susulan di puskesmas bantul 1 sebanyak 23.489 jiwa. Total sebesar 140.929.000 yang harus dibayarkan dari pihak BPJS Kesehatan kepada puskesmas bantul 1 per-satu priode.

\section{Outcome Program Jaminan Kesehatan Nasional (JKN)}

Outcome adalah ukuran kinerja berdasarkan tingkat keberhasilan berdasarkan tujuan program yang sudah dilaksanakan. Dalam mencapai tujuan jamianan kesehatan WHO memberikan pedoman sebagai berikut, pertama adalah seberapa besar persentase penduduk yang dijamin, kedua adalah seberapa lengkap pelayanan yang dijamin , ketiga seberapa besar proporsi biaya langsung yang masih ditanggung oleh penduduk.

1. Persentase Terjaminnya Kesehatan

Badan Penyelenggara Jaminan Sosial (BPJS) adalah badan hukum publik yang dibentuk untuk menyelenggarakan program jaminan sosial. BPJS terdiri dari BPJS Kesehatan dan BPJS Ketenagakerjaan. Sedangkan BPJS Kesehatan adalah badan hukum yang dibentuk untuk menyelenggarakan program jaminan kesehatan. 
Sedangkan secara persentase, cakupan kepesertaan Jaminan Kesehatan Nasional dalam hal ini adalah BPJS Kesehatan adalah sebagai berikut.

\section{Gambar 3}

Cakupan Peserta BPJS Kesehatan

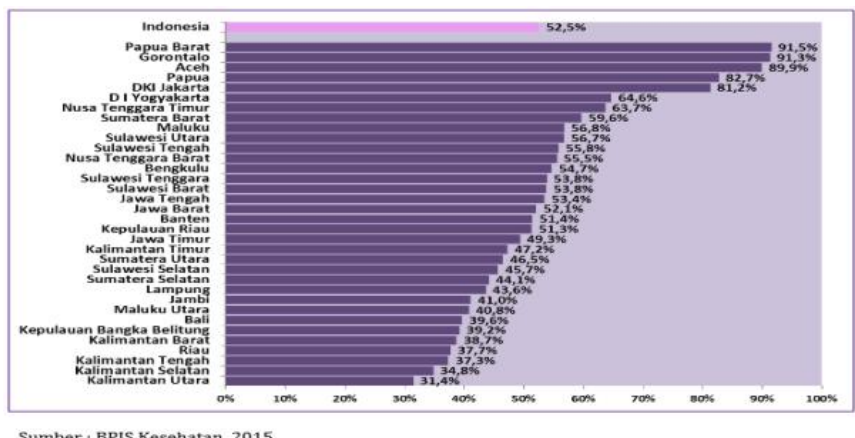

Dari gambar diatas tampak bahwa kepesertaan BPJS Kesehatan di Indonesia (52,5\%) Provinsi D I Yogyakarta ada di urutan ke enam teratas dari selurus provinsi di Indonesia (64,4\%). Kondisi ini menunjukkan kesadaran masyarakat di provinsi D I Yogyakarta untuk menjadi peserta BPJS Kesehatan relatif cukup tinggi.

Kabupaten Bantul sendiri dari hasil registrasi penduduk pada tahun 2015 berjumlah 919.440 jiwa dan yang menjadi peserta asuransi BPJS Kesehatan sebesar 676.276 jiwa (73\%). Kondisi ini menunjukkan bahwa kesadaran masyarakat di Kabupaten Bantul cukup baik untuk menjadi peserta BPJS Kesehatan. 
Menurut [20] pelayanan kesehatan adalah sub sistem pelayanan kesehatan yang tujuan utamanya adalah pelayanan preventif (pencegahan) dan promotif (peningkatan kesehatan) dengan sasaran masyarakat.

Menurut Perpres Nomor 19 Tahun 2016 Pasal 2 Ayat 1 Manfaat pelayanan promotif dan preventif meliputim pemberian pelayanan seperti penyuluhan kesehatan perorangan, imunisasi rutin, keluarga berencana dan skrining kesehatan.

Menurut Peraturan Presiden Nomor 19 Tahun 2016 pasal 22 ayat (1) huruf a dan huruf b menjelaskan pelayanan kesehatan yang dijamin adalah Pelayanan kesehatan tingkat pertama, meliputi pelayanan kesehatan non spesialistik dan Pelayanan kesehatan rujukan tingkat lanjutan.

a. Kualitas pelayanan peserta BPJS Kesehatan di Faskes 1

Tabel 11

Ringkasan Variabel Berdasarkan Kualitas Pelayanan Peserta BPJS Kesehatan di Faskes 1

\begin{tabular}{|l|l|l|l|}
\hline No & Indikator & Nilai Indeks & Ket \\
\hline 1 & Prosedur pelayanan BPJS Kesehatan & 2.30 & Kurang Baik \\
\hline 2 & $\begin{array}{l}\text { Fasilitas memenuhi kebutuhan kesehatan di } \\
\text { puskesmas }\end{array}$ & 2.93 & Baik \\
\hline 3 & $\begin{array}{l}\text { Terjaminya pelayanan pengobatan peseta } \\
\text { BPJS di puskesmas }\end{array}$ & 2.83 & Baik \\
\hline 4 & $\begin{array}{l}\text { Tenaga kesehatan mencukupi pelayanan di } \\
\text { puskesmas }\end{array}$ & 2.84 & Baik \\
\hline Nilai Indeks Rata-Rata & $\mathbf{2 . 7 2}$ & Baik \\
\hline
\end{tabular}

Sumber: Data Diolah Peneliti Hasil Penelitian 
Dari penjelasan diatas, kualitas pelayanan BPJS Kesehatan di Faskes 1 yang ada di Kabupaten Bantul dari nilai indek rata-rata indikator yang ada pada tabel V.18 adalah sebesar 2.72 masuk kedalam kategori baik. Nilai ini dapat diartikan bahwa masyarakat memiliki persepsi bahwa kualitas pelayanan di faske 1 sudah berkategori baik dalam melakukan pelayanan.

3. Ringannya Biaya Kesehatan

Penjelasan Pasal 19 UU SJSN menyatakan bahwa yang dimaksud prinsip asuransi sosial adalah sebagai berikut:

1. Kegotong-royongan antara yang kaya dan miskin, yang sehat dan sakit, yang tua dan muda, dan yang berisiko tinggi dan rendah.

2. Kepesertaan yang bersifat wajib dan tidak selektif.

3. Iuran berdasarkan persentase upah/penghasilan.

4. Bersifat nirlaba.

Prinsip ekuitas yang dimaksud adalah kesamaan dalam memperoleh pelayanan sesuai dengan kebutuhan medis yang terkait dengan besaran iuran yang telah dibayarkan. Kesamaan memperoleh pelayanan adalah kesamaan jangkauan finansial ke pelayanan kesehatan.

Biaya pelayanan yang dicover oleh BPJS Kesehatan di fasilitas tingkat pertama adalah biaya kapitasi maksimal di Puskesmas berdasarkan norma kapitasi yang tersedia yang dijelaskan dalam tabel Tabel 12 sebagai berikuit: 
Tabel 12

Cakupan Pembiayaan Kapitasi di Faskes Tingkat Pertama

\begin{tabular}{|c|l|r|c|c|c|c|c|}
\hline \multicolumn{7}{|l|}{ Norma Kapitasi Puskesmas } \\
\hline lo & Norma Kapitasi & \multicolumn{5}{l|}{ Tarif Kapitasi Maksimal (Rp) } \\
\hline & & 6.000 & 5.500 & 5.000 & 4.500 & 3.500 & 3.000 \\
\hline & & & & & & & \\
\hline & Ketersediaan: & & & & & & \\
\hline 1 & Dokter Umum: & & & $\checkmark$ & $\checkmark$ & & \\
\hline & a. 1 Orang & $\checkmark$ & $\checkmark$ & & & & \\
\hline & b. Minimal 2 Orang & $\checkmark$ & & $\checkmark$ & & $\checkmark$ & \\
\hline 2 & Dokter Gigi & $\checkmark$ & $\checkmark$ & $\checkmark$ & $\checkmark$ & $\checkmark$ & $\checkmark$ \\
\hline 3 & Bidan / Perawat & $\checkmark$ & $\checkmark$ & $\checkmark$ & $\checkmark$ & $\checkmark$ & $\checkmark$ \\
\hline 4 & Laboratorium Sederhana & $\checkmark$ & $\checkmark$ & $\checkmark$ & $\checkmark$ & $\checkmark$ & $\checkmark$ \\
\hline 5 & Apotek / Pelayanan Obat & $\checkmark$ & & \\
\hline
\end{tabular}

Sumber : BPJS Kesehatan

Sedangkan biaya yang dicover oleh BPJS dipelayanan tingkat lanjut/faskes II adalah biaya operasi seperti operasi Jantung, Caesar, Kista, Miom, Tumor, Odontektomi, Bedah Mulut, Usus Buntu, Batu Empedu, Mata, Bedah Vaskuler, Amandel, Katarak, Hernia, Kanker, Kelenjer Getah Bening, Pencabutan Pen, Penggantian Sendi Lutut, Timektomi dan Operasi Ginjal.

Pelayanan kesehatan yang dicover oleh BPJS Kesehatan bisa dimanfaatkan bagi masyarakat yang sudah terdaftar sebagai anggota BPJS. Dan bagi peserta yang ingin memanfaatkan pelayanan yang sudah disediakan oleh BPJS Kesehatan, peserta harus mematuhi persaratan yang sudah ditentukan. 
Biaya pelayanan kesehatan yang dicover oleh BPJS Kesehatan bisa membantu masyarakat dalam meringankan biaya pelayan pengobatan kesehatan di fasilitas tingkat pertama dan tingkat lanjutan. Walaupun biaya kesehatan tidak semua masyarakat dibayarkan oleh pemerintah, bagi masyarakat yang tidak mampu maka baiaya kesehatan akan dibayar oleh pemerintah dengan memberikan asuransi kesehatan.

\section{a. Outcome JKN}

Karakteristik berdasarkan outcome JKN dijelaskan dalam tabel 13 adalah :

Tabel 13

Ringkasan Variabel Outcome JKN

\begin{tabular}{|l|l|l|l|}
\hline No & Indikator & Nilai Indeks & Ket \\
\hline 1 & $\begin{array}{l}\text { Terjaminnya kesehatan dengan menjadi } \\
\text { peserta JKN }\end{array}$ & 3.04 & Baik \\
\hline 2 & $\begin{array}{l}\text { Kesehatan lebih baik dengan menjadi peserta } \\
\text { JKN }\end{array}$ & 3.00 & Baik \\
\hline 3 & $\begin{array}{l}\text { Pelayanan pengobatan menjadi baik dengan } \\
\text { menjadi peserta JKN }\end{array}$ & 3.07 & Baik \\
\hline 4 & $\begin{array}{l}\text { Pembiayaan kesehatan menjadi ringan } \\
\text { dengan menjadi peserta JKN }\end{array}$ & 3.14 & Baik \\
\hline Nilai Indeks Rata-Rata & 3.06 & Baik \\
\hline
\end{tabular}

Sumber: Data Diolah Peneliti Hasil Penelitian

Dari penjelasan diatas, respon peserta BPJS Kesehatan di Kabupaten Bantul terhadap outcome JKN sangat positif, dari nilai indek rata-rata indikator yang ada pada tabel V.24 sebesar 3.06 masuk kedalam kategori Baik. Nilai ini dapat diartikan bahwa masyarakat memiliki persepsi dengan menjadi peserta JKN mempunyai manfaat 
104 dalam pelayanan pengonbatan dan meringankan pembiayaan kesehatan.

\section{KESIMPULAN}

A. Kesimpulan

Berdasarkan uraian yang berkaitan dengan pelaksnaan Jaminan Kesehatan Nasional (JKN) pada bab-bab terdahulu maka dapat ditarik beberapa kesimpulan dan saran sebagai berikut:

1. Ada hubungan antar Stakeholder lembaga BPJS dengan Fasilitas Kesehatan. Pola kerja sama BPJS dengan Fasilitas Kesehatan diatur dalam Peraturan Pemerintah Nomor. 85 Tahun 2013. Kerja sama dilakukan dalam rangka meningkatkan kualitas BPJS Kesehatan atau pelayanan kepada peserta. Secara fungsional BPJS sebagai penjamin pelayanan kesehatan bagi pesertanya dan fasilitas kesehatan salah satunya Rumah Sakit dan Puskesmas adalah pelaksana pelayanan kesehatan. Di Kabupaten Bantul sebanyak 90 Fasilitas Kesehatan yang bekerja sama dengan BPJS dalam rangka meningkatkan pelayanan kesehatan kepada masyarakat. Sosialisasi BPJS terhadap peserta BPJS belum optimal dilihat dari edukasi peserta BPJS yang igin langsung berobat ke fasilitas tingkat lanjut dan peserta tidak memenuhi persyaratan sesuai dengan ketentuan yang sudah ditetapkan. 
2. Model pembiayaan BPJS yang ada saat ini sudah cukup ideal, dari pembayaran BPJS Kesehatan kepada fasiliatas kesehatan tingkat pertama dengan kapitasi, pembayaran BPJS Kesehatan pada tanggal 15 Juni 2016 kepada Puskesmas Bantul 1 sebesar $\mathrm{Rp}$ 140.929.000 dari jumlah peserta yang berobat sebanyak 23.489 jiwa. Sedangkan untuk fasilitas rujukan tingkat lanjut, BPJS Kesehatan membayar dengan sistem paket INA-CBG's, pembayaran BPJS Kesehatan pada tanggal 21 Juni 2016 kepada RSUD Panembahan Senopati sebesar Rp 7.856.997.509 dari pelayanan kesehatan Rawat Inap Tingkat Lanjut (RITL) dan pelayanan kesehatan Rawat Jalan Tingkat Lanjut (RJTL). Sejauh ini pembayaran pihak BPJS Kesehatan kepada fasilitas kesehatan Rumah Sakit dan Puskesmas untuk saat ini masih positif. Dari model pembiayaan BPJS Kesehatan dari nilai indek rata-rata sebesar 2.74. masuk kategori baik. Berdasarkan kualitas pelayanan peserta BPJS Kesehatan di Faskes 1 dari nilai indek rata-rata sebesar 2.78 masuk kategori baik.

3. Outcome Jaminan Kesehatan Nasional (JKN) tingkat keberhasilan cukup baik, dari Persentase terjaminnya kesehatan peserta BPJS sebesar 73\% dari jumlah penduduk di Kabupaten Bantul. Bisa diartikan bahwa persepsi masyarakat cukup positif untuk menjadi peserta BPJS Kesehatan. Pelayanan yang dijamin adalah pelayanan kesehatan tingkat pertama dan pelayanan kesehatan tingkat lanjut. Berdasarkan outcome JKN dari nilai indek rata-rata sebesar 3.06 masuk 
kategori baik. Nilai ini bisa diartikan bahwa peserta BPJS di Kabupaten Bantul memiliki persepsi dengan menjadi peserta JKN dapat meringankan pembiayaan pelayanan kesehatan.

\section{DAFTAR PUSTAKA}

[1] Ratminto dan Atik Septi Winarsih. (2015). Manajemen Pelayanan. Yogyakarata: Pusataka Pelajar.

[2] http://ekbis.sindonews.com/read/1097265/178/kenaikan-iuranbpjs-kesehatan-dib- atalkan-1459427953.

[3] http://economy.okezone.com/read/2016/0/20/320/1292938/ pelayanan-bpjs-keseha- tan-paling-banyak-dikeluhkan.

[4] http://daerah.sindonews.com/read/1031038/189/klaim-bpjsyogya-jebol-1439114015.

[5] http://daerah.sindonews.com/read/1031038/189/klaim-bpjsyogya-jebol-1439114015.

[6] http://www.harianjogja.com/baca/2016/01/24/bpjs-kesehatanpasien-ngotot-dirujuk-biaya-klaim-bpjs-kesehatan-bengkak683837.

[7] Mundiharno. (2012). Peta Jalan Menuju Universal Coverage Jaminan Kesehatan (Road Map to A Universal Health Coverage). Jurnal Legislasi Indonesia ISSN: 0216-1338. Vol. 9 No. 2).

[8] Djogo, Tony dkk. (2003). Kelembagaan Dan Kebijakan Dalam Pengembangan Agroforestri. World Agroforestry Centre (ICRAF) Southeast Asia Regional Office.

[9] Syarif, Maryadi. (2013). Teori dan Model Pengembangan Kelembagaan Pendidikan Tinggi Islam. (Media Akademika, Vol. 28, No. 3).

[10] Iryanie, Emy. (2009). TESIS. Komitmen Stakeholder Perusahaan Terhadap Kinerja Sosial Dan Kinerja Keuangan (Studi Empiris Pada Perusahaan Yang Terdaftar Di Bursa Efek Indonesia). 
[11] Susanto, Yohannes Kurniawan dan Josua Tarigan. (2013). Pengaruh Pengumkapan Sustainability Report Terhadap Profitabilitas Perusahaan. (Business Accounting Review, Vol.1).

[12] Akdon dkk. (2015). Manajemen Pembiayaan Pendidikan. Bandung: Remaja Rosdakarya.

[13] Azwar, Azrul. (1996). Pengantar Administrasi Kesehatan. Jakarta: Sinar Harapan.

[14] Winarno, Budi. (2014). Kebijakan Publik. Yogyakarta: CAPS (Center Of Academic Publishing Service).

[15] Nugroho, Riant. (2009). Public Polici. Jakarta: Alex Media Koputindo.

[16] Sugiyono. (2011). Metode Penelitian Kuantitatif, Kualitatif, Dan Kombinasi (Mixed Methods). Bandung: Alfabeta.

[17] Sugiyono. (2010). Metode Penelitian Kuantitatif \& RND. Bandung: Alfabeta.

[18] Moleong. L. J. (2012). Metode Penelitian Kualitatif. Edisi revisi. Bandung: Remaja Rosdakarya.

[19] Lestari, Endang Dkk. (2011). Sistem Informasi Rekam Medika Pada Rumah Sakit Bersalin Graha Rap Tanjung Balai Karimun. (Jurnal Sistem Informasi (JSI), Vol. 3, No. 2).

[20] Notoatmodjo, Soekidjo. (2010). Metodologi Penelitian Kesehatan. Jakarta : Rineka Cipta. 